\title{
Obesity paradox for critically ill patients may be modified by age: a retrospective observational study from one large database
}

\author{
Dawei Zhou, Zhimin Li, Guangzhi Shi ${ }^{*}$ and Jianxin Zhou*
}

To the Editor:

"Obesity paradox," the phenomenon that obesity increases the risk of obesity-related diseases but paradoxically is associated with a survival benefit, has been observed in some researches related to critical illnesses $[1,2]$. However, the pathophysiologic mechanisms of the obesity survival paradox are currently conjecture. An observational study with a 12-year follow-up in the general population reported that the relative risk for mortality associated with an increased body mass index (BMI) declined with age [3]. However, the short-term effect of age on the association between BMI and in-hospital mortality for critically ill patients is unknown. We therefore aimed to evaluate the effect of age on the "obesity paradox" in an ICU population.

We included all adult patients from the eICU Collaborative Research Database (eicu-crd.mit.edu) that had a first admission to the ICU and whose BMI was $>10$ and $<70 \mathrm{~kg} / \mathrm{m}^{2}$ [4]. Obesity was assessed as a sixcategory variable according to BMI [5]: underweight, $\mathrm{BMI}<18.5 \mathrm{~kg} / \mathrm{m}^{2}$; normal weight, $18.5 \leq \mathrm{BMI}<25 \mathrm{~kg} / \mathrm{m}^{2}$; overweight, $25 \leq \mathrm{BMI}<30 \mathrm{~kg} / \mathrm{m}^{2}$; obesity grade $1,30 \leq$ $\mathrm{BMI}<35 \mathrm{~kg} / \mathrm{m}^{2}$; obesity grade $2,35 \leq \mathrm{BMI}<40 \mathrm{~kg} / \mathrm{m}^{2}$; and obesity grade $3, B M I \geq 40 \mathrm{~kg} / \mathrm{m}^{2}$. The primary endpoint was in-hospital mortality. Hospital mortality was considered as a time-to-event variable. Patients were censored when discharged alive. We used Cox regression analysis to produce adjusted hazard ratios (HRs) for the association between BMI and hospital mortality. The

\footnotetext{
* Correspondence: 15866601260@163.com; bjttyyicu@126.com Department of Critical Care Medicine, Beijing Tiantan Hospital, Capital Medical University, Beijing, China
}

confounders included gender, ethnicity, comorbidities, ICU types, and acute physiology score. BMI was examined as both a categorical and continuous variable. The linear trend for hazard ratio with an increase of 1.0 in BMI across age groups was tested by Cox regression analysis with inverse-variance weighted average. Multiple imputation was used to deal with the missing data.

The final cohort included 148,783 ICU patients, with in-hospital mortality of $9 \%$ (Table 1). 54,572 (36.7\%) patients were classified as obese $\left(B M I \geq 30 \mathrm{~kg} / \mathrm{m}^{2}\right)$. As expected, higher BMI categories had a higher percentage of comorbidities of hypertension, diabetes mellitus, chronic heart failure, and chronic kidney disease. Higher BMI was associated with lower ICU and in-hospital mortality.

When considering normal weight patients as the reference, underweight patients had higher HR for inhospital mortality, while overweight and obesity patients had lower HRs (Fig. 1A). After adjusting for confounders, the association of BMI with mortality was not significant for age $\leq 30,31-40$, and $41-50$ years groups, while mortality was significantly lower with higher BMI for age $51-60,61-70,71-80$, and $\geq 80$ years groups (Fig. 1B, $P$ for trend $<0.001$ ).

The obesity paradox has been hypothesized to result from the extra fat tissue functioning as a fuel source or from the immunomodulatory effects of substances secreted by fat cells $[2,6]$. The age effects could be attributed to older patients are more at risk of malnutrition. Whether the endocrine role of fat in critical illness differs with age has not been investigated. Overall, the potential mechanisms are unclear, which needs further research. The results should be interpreted with caution 
Table 1 Baseline and clinical characteristics of study patients by BMI categories

\begin{tabular}{|c|c|c|c|c|c|c|c|}
\hline Variables & Total & $\begin{array}{l}\text { Underweight } \\
\left(\mathrm{BMI}<18.5 \mathrm{~kg} / \mathrm{m}^{2}\right)\end{array}$ & $\begin{array}{l}\text { Normal weight } \\
\left(18.5 \mathrm{~kg} / \mathrm{m}^{2} \leq \mathrm{BMl}\right. \\
\left.<25 \mathrm{~kg} / \mathrm{m}^{2}\right)\end{array}$ & $\begin{array}{l}\text { Overweight } \\
\left(25 \mathrm{~kg} / \mathrm{m}^{2} \leq \mathrm{BMl}\right. \\
\left.<30 \mathrm{~kg} / \mathrm{m}^{2}\right)\end{array}$ & $\begin{array}{l}\text { Obesity grade } 1 \\
\left(30 \mathrm{~kg} / \mathrm{m}^{2} \leq \mathrm{BMl}\right. \\
\left.<35 \mathrm{~kg} / \mathrm{m}^{2}\right)\end{array}$ & $\begin{array}{l}\text { Obesity grade } 2 \\
\left(35 \mathrm{~kg} / \mathrm{m}^{2} \leq \mathrm{BMI}\right. \\
\left.<40 \mathrm{~kg} / \mathrm{m}^{2}\right)\end{array}$ & $\begin{array}{l}\text { Obesity grade } 3 \\
\left(B M I \geq 40 \mathrm{~kg} / \mathrm{m}^{2}\right)\end{array}$ \\
\hline Number of patients & $148,783(100 \%)$ & $6328(4.3 \%)$ & 43,960 (29.5\%) & 43,923 (29.5\%) & 27,584 (18.5\%) & 13,881 (9.3\%) & 13,107 (8.8\%) \\
\hline \multicolumn{8}{|l|}{ Age } \\
\hline Median, years & $65(53,76)$ & $67(54,80)$ & $67(53,80)$ & $66(54,77)$ & $64(53,74)$ & $62(52,72)$ & $60(49,68)$ \\
\hline$\leq 30$ & $8348(6)$ & $506(8)$ & $3530(8)$ & $2107(5)$ & $1082(4)$ & $544(4)$ & $579(4)$ \\
\hline $31-40$ & $8683(6)$ & $314(5)$ & $2503(6)$ & $2399(5)$ & $1547(6)$ & 891 (6) & $1029(8)$ \\
\hline $41-50$ & $14,947(10)$ & $467(7)$ & 3801 (9) & $4056(9)$ & $2963(11)$ & $1712(12)$ & 1948 (15) \\
\hline $51-60$ & $27,739(19)$ & $1086(17)$ & $6836(16)$ & $7847(18)$ & $5519(20)$ & $3119(22)$ & $3332(25)$ \\
\hline $61-70$ & $33,442(22)$ & $1193(19)$ & $8304(19)$ & $9728(22)$ & $6933(25)$ & $3698(27)$ & $3586(27)$ \\
\hline $71-80$ & $30,823(21)$ & $1277(20)$ & $8604(20)$ & $9926(23)$ & $6179(22)$ & $2790(20)$ & $2047(16)$ \\
\hline$>80$ & $24,801(17)$ & $1485(23)$ & $10,382(24)$ & $7860(18)$ & $3361(12)$ & $1127(8)$ & $586(4)$ \\
\hline Gender: male & $80,294(54)$ & $2669(42)$ & $23,526(54)$ & $26,247(60)$ & $15,617(57)$ & $6973(50)$ & $5262(40)$ \\
\hline $\mathrm{BMI}, \mathrm{kg} / \mathrm{m}^{2}$ & $27.5(23.5,32.7)$ & $17.1(16,17.9)$ & $22.4(20.9,23.7)$ & $27.3(26.1,28.5)$ & $32.1(30.9,33.4)$ & $37(35.9,38.3)$ & $44.7(41.9,49.6)$ \\
\hline \multicolumn{8}{|l|}{ Ethnicity } \\
\hline Caucasian & $114,199(77)$ & 4766 (75) & 33,565 (76) & $33,786(77)$ & $21,462(78)$ & 10,696 (77) & $9924(76)$ \\
\hline African American & $16,537(11)$ & $837(13)$ & $4597(10)$ & $4364(10)$ & $2975(11)$ & $1753(13)$ & $2011(15)$ \\
\hline Hispanic & $5763(4)$ & $197(3)$ & $1754(4)$ & 1909 (4) & $1034(4)$ & $467(3)$ & $402(3)$ \\
\hline Asian & 2494 (2) & $191(3)$ & $1146(3)$ & $745(2)$ & $277(1)$ & $85(1)$ & $50(0)$ \\
\hline Native American & $1090(1)$ & $33(1)$ & $290(1)$ & $303(1)$ & $198(1)$ & $128(1)$ & $138(1)$ \\
\hline Others/unknown & $8700(6)$ & $304(5)$ & $2608(6)$ & $2816(6)$ & $1638(6)$ & $752(5)$ & $582(4)$ \\
\hline \multicolumn{8}{|l|}{ Comorbidities } \\
\hline Hypertension & $74,964(50)$ & $2536(40)$ & $19,663(45)$ & $22,171(50)$ & $15,088(55)$ & $7887(57)$ & $7619(58)$ \\
\hline Diabetes mellitus & $43,420(29)$ & $1058(17)$ & $9333(21)$ & $11,840(27)$ & $9432(34)$ & $5620(40)$ & $6137(47)$ \\
\hline Stroke & $12,315(8)$ & $590(9)$ & $3920(9)$ & $3716(8)$ & $2195(8)$ & $1015(7)$ & $879(7)$ \\
\hline Tumor & $22,356(15)$ & $1295(20)$ & $7465(17)$ & $6674(15)$ & $3736(14)$ & $1772(13)$ & $1414(11)$ \\
\hline Respiratory disease & $22,912(15)$ & $1565(25)$ & $6733(15)$ & $5736(13)$ & $3838(14)$ & $2252(16)$ & $2788(21)$ \\
\hline $\mathrm{CHF}$ & $21,868(15)$ & $734(12)$ & $5683(13)$ & $5904(13)$ & $4164(15)$ & $2463(18)$ & $2920(22)$ \\
\hline Cirrhosis & $4144(3)$ & $175(3)$ & $1308(3)$ & $1224(3)$ & $755(3)$ & $362(3)$ & $320(2)$ \\
\hline CKD & $18,134(12)$ & $663(10)$ & $5131(12)$ & $5186(12)$ & $3441(12)$ & $1813(13)$ & $1900(14)$ \\
\hline \multicolumn{8}{|l|}{ ICU types } \\
\hline Med-Surg|CU & $82,057(55)$ & $3724(59)$ & $24,922(57)$ & $23,652(54)$ & $14,738(53)$ & $7519(54)$ & $7502(57)$ \\
\hline Cardiac ICU & $10,711(7)$ & $511(8)$ & $3047(7)$ & $3148(7)$ & $2028(7)$ & $1000(7)$ & $977(7)$ \\
\hline CCU-CTICU & $12,555(8)$ & 354 (6) & $3186(7)$ & $3894(9)$ & $2655(10)$ & $1371(10)$ & $1095(8)$ \\
\hline CSICU & $5528(4)$ & $183(3)$ & $1492(3)$ & $1802(4)$ & $1114(4)$ & $531(4)$ & $406(3)$ \\
\hline CTICU & $4685(3)$ & $138(2)$ & $1246(3)$ & $1533(3)$ & $1032(4)$ & $457(3)$ & $279(2)$ \\
\hline MICU & $12,758(9)$ & $677(11)$ & 3861 (9) & $3566(8)$ & $2163(8)$ & $1190(9)$ & $1301(10)$ \\
\hline Neuro ICU & $11,245(8)$ & $357(6)$ & $3445(8)$ & $3457(8)$ & $2182(8)$ & $1003(7)$ & 801 (6) \\
\hline SICU & $9244(6)$ & $384(6)$ & 2761 (6) & $2871(7)$ & $1672(6)$ & $810(6)$ & $746(6)$ \\
\hline \multicolumn{8}{|l|}{ ICU scoring systems } \\
\hline SOFA score & $4(2,7)$ & $5(2,7)$ & $4(2,7)$ & $4(2,6)$ & $4(2,6)$ & $4(2,7)$ & $4(2,7)$ \\
\hline APS & $38(27,53)$ & $42(30,59)$ & $38(28,54)$ & $37(26,52)$ & $36(26,52)$ & $37(26,53)$ & $39(27,55)$ \\
\hline APACHE IV score & $50(37,68)$ & $56(42,74)$ & $52(38,69)$ & $50(37,67)$ & $49(36,66)$ & $49(35,66)$ & $49(36,67)$ \\
\hline ICU LOS, days & $2(1,4)$ & $2(1,4)$ & $2(1,4)$ & $2(1,4)$ & $2(1,4)$ & $2(1,4)$ & $2(1,4)$ \\
\hline Hospital LOS, days & $5(3,8)$ & $5(3,9)$ & $5(3,8)$ & $5(3,8)$ & $5(3,8)$ & $5(3,9)$ & $5(3,9)$ \\
\hline ICU mortality & 7938 (5) & $506(8)$ & $2592(6)$ & $2182(5)$ & $1269(5)$ & $705(5)$ & $684(5)$ \\
\hline Hospital mortality & $12,867(9)$ & $897(14)$ & $4289(10)$ & 3536 (8) & $2032(7)$ & $1064(8)$ & $1049(8)$ \\
\hline
\end{tabular}

Data are median (interquartile range) or no./total (\%)

$B M I$ body mass index, CHF chronic heart failure, CKD chronic kidney disease, ICU intensive care unit, CCU coronary care unit, CTICU cardiothoracic ICU, CSICU cardiac surgery ICU, MICU medical ICU, SICU surgical ICU, SOFA Sequential Organ Failure Assessment, APS Acute Physiology Score, APACHE Acute Physiology and Chronic Health Evaluation, LOS length of stay 


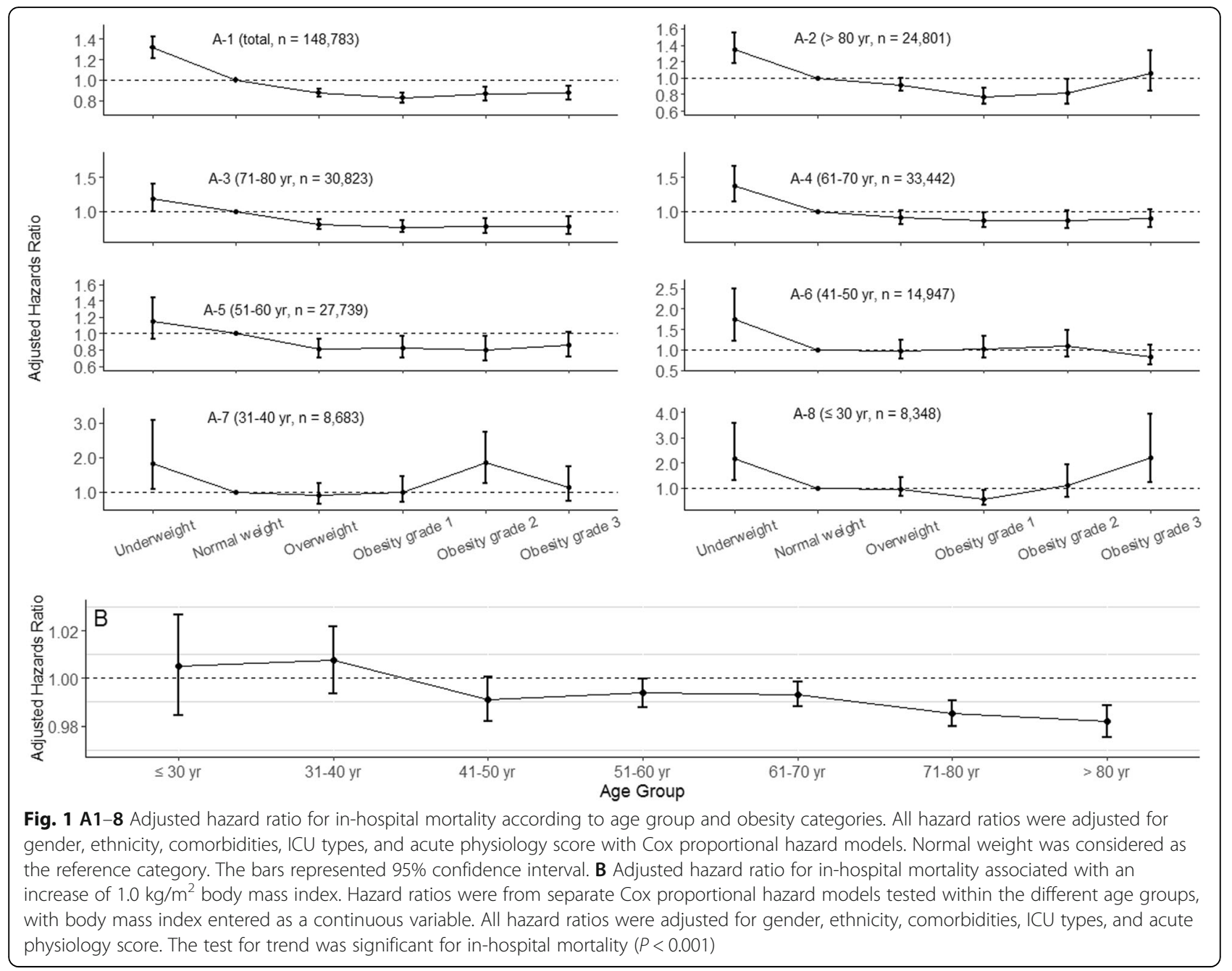

because of the limitations, such as the retrospective nature, the risk of residual confounding, and the missing data of BMI. The prevalence of obesity is increasing, also in the ICU population [2], and acknowledging the differential impact of obesity on mortality according to age class may help to improve outcome prediction.

In conclusion, our data are in concert with the obesity paradox and suggest that age has a modifying effect on the association between BMI and in-hospital mortality. Overweight or obesity may be more beneficial for older adult critically ill patients. Further study is needed to investigate the potential mechanisms.

\section{Abbreviations}

BMI: Body mass index; HR: Hazard ratio; ICU: Intensive care unit

\section{Acknowledgements}

None.

\section{Authors' contributions}

DW Z and JX Z conceived this study. DW Z extracted the data. DW Z, ZM L, and GZ $S$ designed and performed the statistical analyses. DW Z wrote the first draft of the manuscript. GZ S and JX Z reviewed and modified the final manuscript. All authors read, critically reviewed, and approved the final manuscript.

\section{Funding}

This study was supported by the "Beijing Municipal Science and Technology Commission-Capital clinical application research" (Z181100001718068). The sponsor had no role in the study design, data collection, data analysis, data interpretation, or writing of the manuscript.

\section{Availability of data and materials}

Data analyzed during the present study are currently stored in the elCU database (eicu-crd.mit.edu). After completing the required training course (the Collaborative Institutional Training Initiative) and requesting access to the elCU Collaborative Research Database, researchers can seek to use the database.

\section{Ethics approval and consent to participate}

The schema of elCU was established in collaboration with Privacert (Cambridge, MA), who certified the re-identification risk as meeting safe harbor standards (HIPAA Certification no. 1031219-2). All tables in elCU were deidentified to meet the safe harbor provision of the US HIPAA. Due to the HIPAA compliant de-identification in this database, our IRB requirement was waived.

\section{Consent for publication}

Not applicable. 


\section{Competing interests}

None of the authors has declared a conflict of interest.

Received: 5 March 2020 Accepted: 5 July 2020

Published online: 13 July 2020

\section{References}

1. Hogue CW Jr, Stearns JD, Colantuoni E, Robinson KA, Stierer T, Mitter N, Pronovost PJ, Needham DM. The impact of obesity on outcomes after critical illness: a meta-analysis. Intensive Care Med. 2009;35(7):1152-70

2. Schetz M, De Jong A, Deane AM, Druml W, Hemelaar P, Pelosi P, Pickkers P, Reintam-Blaser A, Roberts J, Sakr Y, et al. Obesity in the critically ill: a narrative review. Intensive Care Med. 2019;45(6):757-69.

3. Stevens J, Cai J, Pamuk ER, Williamson DF, Thun MJ, Wood JL. The effect of age on the association between body-mass index and mortality. N Engl J Med. 1998;338(1):1-7.

4. Pollard TJ, Johnson AEW, Raffa JD, Celi LA, Mark RG, Badawi O. The elCU Collaborative Research Database, a freely available multi-center database for critical care research. Scientific data. 2018:5:180178.

5. Executive summary of the clinical guidelines on the identification, evaluation, and treatment of overweight and obesity in adults. Arch Intern Med 1998, 158(17):1855-1867.

6. Marques MB, Langouche L. Endocrine, metabolic, and morphologic alterations of adipose tissue during critical illness. Crit Care Med. 2013;41(1): $317-25$

\section{Publisher's Note}

Springer Nature remains neutral with regard to jurisdictional claims in published maps and institutional affiliations.

- fast, convenient online submission

- thorough peer review by experienced researchers in your field

- rapid publication on acceptance

- support for research data, including large and complex data types

- gold Open Access which fosters wider collaboration and increased citations

- maximum visibility for your research: over $100 \mathrm{M}$ website views per year

At BMC, research is always in progress. 